\title{
The Role of Psychological Capital on Employee Voice: Conservation Resources Framework
}

\author{
Unika Prihatsanti \\ Psychology Faculty, \\ Universitas Diponegoro Semarang \\ Doctoral Program, Psychology Faculty, \\ Universitas Airlangga, Surabaya \\ unikasantie@gmail.com \\ Rahkman Ardi \\ Psychology Faculty, \\ Universitas Airlangga, Surabaya \\ rahkman.ardi@psikologi.unair.ac.id
}

\author{
Seger Handoyo \\ Psychology Faculty, \\ Universitas Airlangga, Surabaya \\ seger.handoyo@psikologi.unair.ac.id
}

\author{
Puji Tania Meliala \\ Psychology Faculty, \\ Universitas Atmajaya, Jakarta \\ pujitania@gmail.com
}

\begin{abstract}
The current study aims to explain how psychological capital influences employee voice in the Indonesian context. The conservation resources framework can provide an explanation of how personal resources, namely psychological capital (psycap) have an impact on work behavior (employee voice). This study involved 182 participants from various companies. Questionnaires were circulated via an instant messaging application, several social media platforms, and paper-based. Based on a simple regression analysis, it is proven that psychological capital is significantly related to employee voice. Employees can choose to speak up when they are motivated by a pro-social motive that brings to constructive changes to themselves and the organizations. Psycap interacting simultaneously produces different manifestations, which can make individuals obtain new resources. By acquiring these additional resources, individuals are ready to meet the demands of work and achieve their work goals, by providing a voice.
\end{abstract}

Keywords: Conservation resources, promotive, prohibitive, psychological capital, resources.

Received 2 January 2020/Accepted 27 May 2020 CJEHCP All rights reserved

\section{Introduction}

Employees' participation has always been considered as an appealing topic for researchers and practitioners since Hugo Munsterberg wrote on the importance of collaboration between management and employees in 1913 (Glew, O’leary-Kelly, Griffin \& Van Fleet, 1995). Employee voice is a part of participation in an organization. In addition, employee voice is a form of communication among employees conducted voluntarily and open in order to influence the 


\section{Journal of Educational, Health and Community Psychology Prihatsanti, Vol 9, No 2, 2020 E-ISSN 2460-8467 Handoyo,

organization's working context such as policy, practice and operating procedures (Van Dyne \& LePine, 1998; Morrison, 201I, 2014). Employee voice enables members of organization to gain more knowledge from their mistakes and weaknesses making the organization to perform more effectively (Detert, Burris \& Harrison, 2010) which, eventually, can prevent financial loss (Bai, Lin, \& Liu, 2017).

Employee voice has become the integral part of an organization's internal communication and attractive topic to be discussed further and deeper (Constantin \& Baias, 20I5). In some cases, communication barrier is often irrational and contra-productive in which the employees feel excluded from the organization (Sirota \& Klein, 2014). Despite the importance of voice in an organization's effectiveness (Detert \& Burris, 20I0), not all employees are interested in engaging themselves to produce voice (Zare \& Flinchbaugh, 2018). Several studies indicated that they are hesitant to discuss about problems at work or suggest improvements to the company due to the fear in the negative impact they may bear. (Morrison, 201I; Detert \& Burris, 2010; Morrison \& Milliken, 2000; Milliken, Morrison \& Hewlin, 2003; Tangirala \& Ramanujam, 2008).

Researchers have explored the antecedents of employee voice as an interesting phenomenon especially when dealing with individual issues like working attitude (Van Dyne \& LePine, 1999) and dispositional factor (Zare \& Flinchbaugh, 2018). They realize the importance of individual differences as it affects the decision making process of whether they choose to speak up their mind or remain silent (Botero, 2013). In spite of its influential contribution to researches on employee voice, more studies are required to discover voice antecedents (Morrison, 20I4). This is related to the limited studies exploring the individual differences which affect employee voice including demography that requires more attention (Botero,2 013; Hatipoglu \& Inelmen, 2017). Furthermore, there are few studies considered demography variable in employee voice literature (Hatipoglu \& Inelmen, 2017). Second, Zare meta-analysis study discovered that previous researchers focused more on the big five personality factors which influence employee voice resulting on the gap in exploring other individual factors (Zare \& Flinchbaugh, 2018). Third, literature reviews have explained that the antecedents and consequent of employee voice have not made personal resources influential enough to employee voice (Bottero, 2013; Morrison, 20II, 20I4; Chamberlin, Newton \& LePine, 2017; Wang \& Zheng, 2018). In line with conservation resources (COR) 


\section{Journal of Educational, Health and Community Psychology Prihatsanti, Vol 9, No 2, 2020 E-ISSN 2460-8467 Handoyo, Ardi, Meliala}

framework, individual with more resources is able to deal with working demand and accomplish the desired goals. Limited researches have tried to explain the relation of personal resources, in this case, psychological capital (psycap) with employee voice (Wang \& Zheng, 2018; Wang \& Yuan, 2017). Thus, this research aims to answer the question (a) Does psycap affect employee voice? (b) are there any differences in terms of demographic diversity in employee voice?

An employee can choose to give his/her voice when they are motivated by their pro-social motive (Van Dyne \& LePine, 1998), which aims to bring constructive transformation for one self and the organization. Also, one can choose to give his/her voice to take risk by challenging the status quo (Morrison, 20II) which can ruin the good relationship with co-workers or superiors (Liu, Zhu \& Yang, 2010). Voice requires enough personal resources like self-efficacy (Morrison, 20II,20I4). Efficacy is an individual's belief in putting his/her finest efforts to finish the task in any given condition. Previous researches have proven that efficacy has crucially affected employee voice (Prihatsanti, Handoyo \& Ardi, Inpress; Duan, Kwan \& Ling, 20I4). Efficacy is the key component in building a person's psycap. This psycap can be developed and invested to lead the individual competition continuously. Since managing the organization effectively requires new paradigm in which the eminence and benefits of continuous competition is no longer dependent on physical, financial and technology resources. Instead, it focuses more on the human resources (Luthans, Youssef \& Avolio, 2007). Furthermore, it is described that psycap is a personal resource which can be developed and managed effectively to improve performance (Luthans et al, 2007).

In attempts of responding to the question, researchers used conservation resources (COR) framework which states that an individual has degradable or upgradable resources. The main principle lies in the individual efforts to seek or obtain new resources which can protect oneself from the loss of bigger resources (Hobfoll, 1989). Limited resources (i.e. physical resources, emotional resources, personal resources) can motivate an individual to protect these resources and engage a behavior to accumulate additional resources which can be useful in the future (Hobfoll, 1989). Psycap is a personal resource that can be used (Luthans, Morgan \& Avolio, 2015). PsyCapis defined as a person's positive psychological condition consisting of self-efficacy in taking action and putting the best efforts to accomplish challenging tasks, positive attribute (optimism) in present and 


\section{Journal of Educational, Health and Community Psychology Prihatsanti, Vol 9, No 2, 2020 E-ISSN 2460-8467 Handoyo, Ardi, Meliala}

future success, perseverance in reaching the goals (hope), and durability when dealing with problems and misery in order to bounce back to reach success (resiliency) (Luthans et al, 2007).

Various psycap effects have been studied in various levels (Newman, Uchasaran, Zhu \& Hirst, 2014). For example, in individual level, it contributes in working attitude (commitment, satisfaction, and intention turnover), employee's attitude (attendance, contra-productive behavior, and citizenship behavior), performance (innovative behavior and performance), and safety atmosphere. In group level, psycap affects the group's performance while in organizational level it affects the organization's performance. Researches also showed that psycap is a mediator for leadership faktor and employee voice (Wang \& Zheng, 2017; Wang \& Yuan, 2017). In Indonesia, the research on the topic also attracts many researchers' attention. Psycap affects working satisfaction, innovative behavior, attachments and citizenship (Prihatsanti, Handoyo \& Ardi, 2018).

Taking all the consideration into account, this research can provide the required contribution in voice literature by exploring the relationship between personal resources (psycap) and employee voice which can be explained through the relationship mechanism between both variables by using COR framework.

\section{Method}

\section{Participant}

All participants provided a inform consent of willingness to answer the question related to psychological capital and employee voice before they participated in this study. The provision of inform consent was approved by the Research Ethics Committee, Faculty of Psychology, Airlangga University, Surabaya, Indonesia. The sample was 182 subjects; all are Indonesian people coming from various companies who have minimum I year experience. Convinience sampling used to take the data. Table I depicts the participants' detail demography variable. 
Table I

Descriptive Statistic Demography $(\mathrm{N}=182)$

\begin{tabular}{llcc}
\hline Demographic & & Frequency & Percentage \\
\hline Gender & Male & 88 & 48.4 \\
& Female & 94 & 51.6 \\
Education & Secondary & 36 & 19.8 \\
& Diploma & & \\
& Bachelor & 113 & 62.1 \\
\multirow{5}{*}{ Tenure } & Master & 33 & 18.1 \\
& $<5$ years & 105 & 57.7 \\
& $>5$ years & 77 & 42.3 \\
\hline
\end{tabular}

\section{Procedure}

This research used two survey methods: (a) online administered scale via instant messaging application and social media platform, (b) pencil paper based administered scale. All participants were informed about the aim of the research and were convinced that their identity would be kept secret (anonymous).

Instruments

All instruments used in the research were translated from English to Indonesian by applying back translation procedure (Brislin, 1970). The scale was filled using likert 5 point scale.

\section{Employee Voice}

Employee voice was measured using Liang et al scale (Liang, Farh \& Farh, 20I2) to measure individual employee voice which consists of 5 promotive voice items and 5 prohibitive voice items. Sample items like "develop and make suggestions for issues that may influence the group" (promotive voice) and "voice out opinions on things that might affect the efficiency in the work unit, even if that would embarrass others" (prohibitive voice). Alpha coefficient .86

\section{Psychological Capital}

Psychological capital was measured by applying Psychological Capital Questionnaire (PCQ-24) (Luthans et al, 2007) which consists of 24 items to measure individual psychological capital. Sample items like "I feel confident helping to set targers/goals in my work area (self-efficacy), "I can think of may 
ways to reach my current work goals (hope), "I ussually manage difficulties one way of another at work" (resilience), "I always look on the bright side of thins regarding my job" (optimism). Alpha coefficient .86

\section{Data Analysis}

Simple regression analysis was applied to assess the relationship between psycap and employee voice. Statistical analysis used Jamovi software Version 0.9 (Jamovi Project). Researchers also calculate the effect size and post hoc or achieved statistical power with G*Power (Faul, Erdfelder \& Lang, 2007).

\section{Results}

Regression analysis result showed correlation between psycap and employee voice $(r=0,385$, $\mathrm{p}<0.00 \mathrm{I})$ which means that psychological capital is a significant predictor in employee voice. This assumption was confirmed by the linear regression analysis in table 2 .

Table 2

Determinant of Psychological Capital (Psycap) to Employee Voice $(N=182)$

\begin{tabular}{|c|c|c|c|c|c|c|c|}
\hline Variables & Unstandardized B & SE & $\mathrm{F}$ & $\mathrm{p}$-value & $\mathrm{aR}^{2}$ & VIF & $\begin{array}{l}\text { Power } \\
(1-\beta)\end{array}$ \\
\hline $\begin{array}{l}\text { Psycap } \\
\text { Constant }\end{array}$ & 13.782 & 4.016 & 31.335 & $.000 *$ & .144 & 1.000 & 1.00 \\
\hline EV & 0.204 & 0.036 & & $.000 *$ & & & \\
\hline
\end{tabular}

\footnotetext{
${ }^{2} \mathrm{SE}=$ standard error, $\mathrm{aR}{ }^{2}=$ adjusted $\mathrm{R}^{2}$, VIF = collinearity diagnostics, $\mathrm{I}-\beta=$ achieved statistical power, ${ }^{*} \mathrm{p}<0.0 \mathrm{I}$.
}

Table 3

Correlations Matrix ( $N=$ /82)

\begin{tabular}{lccll}
\hline Dimensions Psycap & M & SD & \multicolumn{2}{c}{ Employee Voice } \\
\cline { 4 - 5 } & & & $\boldsymbol{r}$ & $\mathbf{P}$ \\
\hline Self-Efficacy & 28.3 & 4.02 & .402 & $.000^{* *}$ \\
Hope & 28.2 & 3.85 & .373 & $.000^{* *}$ \\
Resilience & 26.0 & 3.50 & .253 & $.00 \mathrm{I}^{* *}$ \\
Optimism & 27.1 & 3.76 & .146 & $.049^{*}$ \\
\hline 3** correlation is significant at the 0.01 level; "correlation is significant at the 0.05
\end{tabular}




\section{Journal of Educational, Health and Community Psychology Prihatsanti, Vol 9, No 2, 2020 E-ISSN 2460-8467 Handoyo, Ardi, Meliala}

In table 3, Pearson correlation indicates significant correlation between psycap dimensions, namely self-efficacy, hope, resilience and optimism and employee voice.

Table 4

The different demographic variable and employee voice $(N=182)$

\begin{tabular}{|c|c|c|c|c|c|c|c|c|c|c|}
\hline & Demographic & $n$ & Mean & SD & $\begin{array}{l}\text { Levene's } \\
\text { Test }\end{array}$ & $\mathrm{t}$ & $d f$ & $P$ & Cohen's d & $\begin{array}{l}\text { Power } \\
\qquad(1-\beta)\end{array}$ \\
\hline \multirow[t]{2}{*}{ Gender } & Male & 88 & 37.58 & 6.039 & .554 & 3.123 & 180 & .002 & 0.463 & 1.00 \\
\hline & Female & 94 & 34.78 & 6.017 & & & & & & \\
\hline \multirow[t]{2}{*}{ Education } & Middle & 36 & 36.111 & 6.541 & .818 & 0.28 & 180 & .977 & .005 & 1.00 \\
\hline & High & 146 & 36.144 & 6.101 & & & & & & \\
\hline \multirow[t]{2}{*}{ Tenure } & $<5$ & 105 & 35.762 & 5.379 & .065 & .095 & 180 & .339 & .14 & 1.00 \\
\hline & $>5$ & 77 & 36.649 & 7.118 & & & & & & \\
\hline
\end{tabular}

Table 4 indicates that the independent sample t-test result on both groups; gender, generation, education, and tenure showed Levene's test value of $>0.05$ which means that both groups were equal. Thus equal variances assumption was used. Employee voice $(t(I 82)=3.123, p=0.002, d=0.463)$ significantly distinguished both gender groups. Also, there were some differences found in education and tenure groups but not significant.

\section{Discussion}

Positive corelation between psychological capital and employee voice indicated that psychological capital contributed to employee voice. The challenge in delivering employee voice was the extra personal cost when the management refuse to even consider the input given by the employee. In this case, voice was considered risky and thrilling ( $\mathrm{Ng} \&$ Feldman, 20I2).

Based on COR framework, when employees possess high psycap, they tend to give their voice. It is supported by the results from previous researches which stated that they will engage in voice behavior when they have sufficient resources (Morrison, 20II), since they will not have the burden of spending their resources. On the contrary, when employees have lack of resources such as 


\section{Journal of Educational, Health and Community Psychology Prihatsanti, Vol 9, No 2, 2020 E-ISSN 2460-8467 Handoyo, Ardi, Meliala}

efficacy, hope, optimism, and resilience, they will be reluctant to produce voice because it will cost them their energy or resources.

Voice is a surpressing condition for some employees which can only be handled when they have enough psycap to prevent resources depletion. Employees with high self-efficacy have the ability and skill to provide input to the organization. Second, hope is the ability of self-directing to achieve the desired goal persistently. Therefore, employees with high hope will always find their way to produce voice. Third, employees with high resilience will be able to bounce back when facing failure.

They have coping ability to adapt with hostile environment, stresfull and very dysfunctional for both individual and organizational. Optimism is the belief in considering the desired goal as a part of power and control which will ripple in the future despite the ever changing situation. It can make an individual able to accept failure and rise back again to keep struggling. This can only happen when individual believes in one's ability to weather the storm and come out succesfully (Seligman, 20 I I). This individual will be more productive and open to new ideas. Such open minded perspective transforms individual to be able to communicate ideas, suggestion, concern and opinion of any work relating issues (Morrison, 201 I, 2014).

Demographic diversity affects working practice in an organization (Hatipoglu \& Inelmen, 2017). Research showed that there was different demography variable in the employee voice. Consistent to the previous researches, there was gender difference in employee voice (Wang \& Yuan, 2017). Male employees tended to be more active in producing voice rather than their female counterpart as shown at table 4. This happened due to the paternalistic culture in Indonesia which put men on the top of the hierarchy structure. Therefore, males will perform as the authority figure (Irawanto, 20II) which allows them to produce voice more often. Second, there are differences in tenure as shown in table 4, these result need to be interpreted more carefully. Employees with shorter tenure felt that they had less control on the situation compared to those who had more experience in producing voice (Humborstad \& Dysvik, 2016). 


\section{Journal of Educational, Health and Community Psychology Prihatsanti, Vol 9, No 2, 2020 E-ISSN 2460-8467 Handoyo, Ardi, Meliala}

This research provides theoritical contribution to describe the connection between psychological capital and employee voice. Also, the research provides practical implication for managers to give their employees the opportunity to improve their psychological capital. Psychological capital is a positive psychological capacity which can be developed (Prihatsanti et al, in press) by giving positive experiences to the employees in producing their voice.

This research possessed several limitations as the data were taken cross-sectionally via online media and obtained from a single source which allows common method bias. Hence, the next study needs to collect the data from various sources. Secondly, the demographic variable included in the research has not fully explored how the interaction mechanism occured. Thus, it opens the opportunity for the next research to study the connection between demographic diversity and employee voice. Thirdly, researchers in this research did not control the type of company which may affect the final result.

\section{Conclusion}

Psychological capital contributes to employee voice. Psychological capital is an individual's internal resources. Sufficient internal sources can encourage individuals or employees to speak up. Therefore employees need to improve psycap by involving the organization where they work. This positive psychological capital is important. Employee believe they have the ability (efficacy), find their way to produce voice (hope), bounce back when facing failure and adapt with not supported environtment (resilience) and belief in considering the desired goal as a part of power and control (optimism). Efficacy, hope, resilience, optimism can encourage to provide voice in organization. Only gender showed significant evidence to affect voice.

\section{Acknowledgement}

Program Bantuan Seminar Luar Negeri, Ditjen Penguatan Riset dan Pengembangan, Kemenristekdikti for the travel grants to Moscow, Russia. 


\section{References}

Bai, Y., Lin, L., \& Liu, J. T. (20I7). Leveraging the employee voice: a multi-level social learning perspective of ethical leadership. International Journal of Human Resource Management, 5192, I-33. DOI. 10.1080/09585I92.2017.13084I4

Brislin, R. W. (1970). Back-translation for cross-cultural research. Journal of Cross Cultural Psychology, I, I85-2I6. DOI. I0.II77/I359/0457000I0030I.

Budd, J., Gollan, P. J. \& Wilkinson, A. (2010). New approaches to employee voice and participation in organizations. Human Relations, I-I4, DOI. I0.III 7/0018726709348938.

Botero, I. C. (20I3). Individual correlates employee voice: What do we know so far? Where should we go next?. In Voice and Whistleblowing in Organizations: Overcoming Fear, Fostering Courage and Unleasing Candor, 2nd ed.; Burke, R.J., Cooper, C.L., Eds.; Publisher: Northmanton, MA, USA, PP. 75-89, ISBN.978I78I0059I0.

Chamberlin, M., Newton, D. W. \& Lepine, J. A. (2017). A Meta-Analysis of Voice and Its Promotive and Prohibitive Forms: Identification of Key Associations, Distinctions, and Future Research Directions. Personnel Psychology, 70(I), II-7I. DOI. 10.1 III/peps. 12185

Constantin, E. C., \& Baias, C. C. (2015). Employee voice-key factor in internal communication. Procedia-Social and Behavioral Sciences, I9I, 975-978. DOI. 10.1016/j.sbspro.2015.04.319.

Detert, J.R.; Burris, E.R. \& Harrison, D.A. (2010). Debunking four myths about employee silence. Havard Business Review, 88(6), 26-39.

Duan, J., Kwan, H. K. \& Ling, B. (20I4). The role of voice efficacy in the formation of voice behaviour: A cross-level examination. Journal of Management and Organization, 20(4), 526-543. DOI. 10.1017/jmo.2014.40

Faul, F., Erdfelder, E.; Lang, A-G., \& Buchner, A. (2007). G*Power 3: A flexible statistical power analysis program for the social, behavioral, and biomedical sciences. Behavior Research Methods, 39(2), |75-19|

Glew, D.J., O'Leary-Kelly, A.M., Griffin, R.W., \& Van Fleet, D.D. (1995). Participation in organizations: A preview of the issues and proposed framework for future analysis. Journal of Management, 2I, 395-42I, DOI. I0.I I77/0I4920639502I00302.

Hatipoglu, C., \& Inelmen, K. (2017). Demographic diversity in the workplace and its impact on employee voice: the role of trust in the employeer. Journal of Human Resource Management, 225. DOI. 10.1080/09585192.2017.1322120.

Hobfoll, S. E. (1989). A new attempt at conceptualizing stress. American Psychologist, 44(3), 5 I 3.

Humborstad, S. I. \& Dysvik, A. (2016). Organizational tenure and mastery-avoidance goals: The moderating role of psychological empowerment. The International Journal of Human Resource Management, 27, |237-I25I. 
Irawanto, D.W. (20II). Exploring paternalistic leadership and its application to the Indonesian context. Database Proquest Dissertations \& Theses. Massey University, Palmersion North New Zealand.

Jamovi Project. Jamovi (Version, 0.9) [computer software]. Retreived from https://www.jamovi.org.

Lakens, D. (2014). Performing high-powered studies efficiently with sequential analyses: Sequential analyses. European Journal of Social Psychology, 44(7), 70I-7I0. DOI. I0.1002/ejsp.2023

Liang, J., Farh, C. I. \& Farh, J. L. (2012). Psychological Antecedents of Promotive and Prohibitive Voice: a Two-Wave Examination, Academy of Management Journal,55(I), 7I-92. DOI. 10.5465/amj.2010.0176

Liu, W., Zhu, R. \& Yang, Y. (2010).I warn your because I like you: Voice behavior, employee identifications, and transformational leadership. The Leadership Quarterly, 2I, I89-202. DOI. bx7rxq

Luthans, F., Youssef, C. M. \& Avolio, B.J. (2007).Psychological Capital: Developing the human competitive edge.; Publisher: Oxford University Press, New York.

Luthans, F., Morgan, C. M. \& Avolio, B. J. (2015).Psychological capital and beyond. Publisher: Oxford University Press, New York.

Milliken, F. J., Morrison, E.W. \& Hewlin, P. F. (2003). An exploratory study of employee silence: Issues that employees don't communicate upward and why. Journal of Management Studies, 40, | 453-|476. DOI. 10.1 I I I/I467-6486.00387

Morrison, E. W. (20II). Employee voice behavior: Integration and directions for future research. Academy of Management Annals, 5(I), 373-4I2. DOI. 10.1080/194I6520.201 I.574506

Morrison, E. W. (2014). Employee Voice and Silence. Annual Review of Organizational Psychology and Organizational Behavior, I(I), I73-197. DOI. I0.I I46/annurev-orgpsych-03 I4I3-09I328

Morrison, E. W. \& Milliken, F. J. (2000). A barrier organizational silence: to change and development in a pluralistic world, Academy of Management Review, 25(4), 706-725.

Newman, A., Ucbasaran, D., Zhu, F. \& Hirst, G. (2014). Psychological capital: A review and synthesis. Journal of Organizational Behaviour, 35, I20-138. DOI. 10.1002/job.1916.

$\mathrm{Ng}$, T. W. H. \& Feldman, D. C. (20I2). Employee voice behavior: a meta-analytic test of the conservation of resources framework. Journal of Organizational Behavior, 33, 216-234. DOI. 10.1002/job.754

Prihatsanti, U., Handoyo, S. H., \& Ardi, R. (2018).Employee's voice behavior: A Literature review and conceptual development. Proceedings The $6^{\text {th }}$ ASEAN Regional Union Psychological Society (ARUPS) Congress.

Prihatsanti, U., Handoyo, S.H. \& Ardi, R. (inpress).I am sure I can speak up: The role of efficacy on employee voice. Proceedings International Conference on Psychology. 
Seligman, M.E.P. (201 I). Learned optimism. Retreived from https://books.google.com/books?isbn=030780334I

Sirota, D., \& Klein, D. A. (20I4). The Enthusiastic Employee: How Companies Profit by Giving Workers What They Want, 2nd ed.; Publisher: Pearson Education Inc, New Jersey, ISBN. 1978-0-I3324902-6

Tangirala, S., \& Ramanujam, R. (2008). Employee silence on critical work issues: The cross-level effects of procedural justice climate. Personnel Psychology, 6I, 37-68.

Van Dyne, L., \& LePine, J. A. (1998). Helping and voice extra-role behaviors: Evidence of construct and predictive validity. Academy of Management Journal, 4 I (I), I08-I I 9. DOI. 10.2307/256902.

Wang, Y., \& Zheng, Y. (2018). How transformational leadership influences employee voice behavior: The roles of psychological capital and organizational identification. Social Behavior and Personality, 46(2), 313-322. DOI. 10.2224/sbp.6619.

Wang, Y., \& Yuan, C. (2017). Coaching leadership and employee voice behavior: A multilevel study. Social Behavior and Personality, 45(I0), I655-I664. DOI. 10.2224/sbp.6593.

Zare, M., \& Flinchbaugh, C. (2018). Voice, creativity, and bid five personality traits: A Meta-Analysis. Human Performance, 2-22. DOI. 10.1080/08959285.2018.1550782. 